Deivys Moises Alvarez Garcia

\title{
Systematics of the tribe Telothyriini Townsend, 1927 (Diptera: Tachinidae)
}

Sistemática da tribo Telothyriini Townsend, 1927 (Diptera: Tachinidae) 


\begin{abstract}
Telothyriini is a peculiar tribe of subfamily Dexiinae (Diptera, Tachinidae), restricted to America. These flies are endoparasitoid that attack several families of Lepidotera, including some agricultural pests, and also are an important component of the parasitoid insect community in natural ecosystems. Despite its importance, this tribe has serious taxonomic problems, many of its species appear to be synonymous, its monophyly has never been tested and its phylogenetic relationships are totally unknown. For this, we present here the first systematic revision (taxonomic and phylogenetic) of tribe Telothyriini. The taxonomic work was based on an exhaustive morphologic analysis that included the examination of type specimens and a large number of non-type specimens of each species. The validity of each taxon was determined by the comparative analysis of external features and the terminalia. For the phylogenetic analysis, a matrix with 107 morphologic characters was constructed, and the search for trees was carried out under parsimony criterion. Of the 46 nominal species included in the tribe prior to this revision, 22 are considered as valid, 24 synonyms are proposed, and six new species are described; in this way, the tribe now becomes composed of 28 species. We provide a key to species, as well as detailed descriptions that include photographs and illustrations of adults and terminalia. Furthermore, the tribe is registered for the first time in ten countries, twelve species have new geographic records in different administrative units (country, state, or province), and eleven species are recorded for the first time in at least one country. Our phylogenetic analysis recovered Telothyriini as a monophyletic clade, and according to our criteria the tribe should remain monogeneric, with genus Telothyria only. The ancestral state reconstruction suggests that the ancestor of Telothyriini did not have feathery hairs on disc of mesonotum, and that transition to a hairy mesonotum occurred three times independently, in one of which a later transition from long to short feathery hairs was achieved. Finally, we consider feathery hairs a convergent character among Telothyriini and bees.
\end{abstract}

Keywords: Ancestral state reconstruction. Convergence. Feathery hairs. New record. Parasitoid. Parsimony. Phylogeny. Tachinid. Taxonomy. Telothyria. 


\section{RESUMO}

Telothyriini é uma tribo peculiar da subfamília Dexiinae (Diptera, Tachinidae), restrita à América. Essas moscas são endoparasitoides que atacam várias famílias de Lepidotera, incluindo algumas pragas agrícolas, mas também são um componente importante da comunidade de insetos parasitoides em ecossistemas naturais. Apesar de sua importância, esta tribo apresenta sérios problemas taxonômicos, muitas de suas espécies parecem ser sinônimos, sua monofilia nunca foi testada e suas relações filogenéticas são totalmente desconhecidas. Apesar de sua importância, esta tribo apresenta sérios problemas taxonômicos, muitas de suas espécies parecem ser sinônimos, sua monofilia nunca foi testada e suas relações filogenéticas são totalmente desconhecidas. Por isso, apresentamos aqui a primeira revisão sistemática (taxonômica e filogenética) da tribo Telothyriini. O trabalho taxonômico foi baseado em uma análise morfológica exaustiva que incluiu o exame de espécimes-tipo e um grande número de espécimes não-tipo de cada espécie. A validade de cada táxon foi determinada pela análise comparativa das características externas e da terminália. Para a análise filogenética, foi construída uma matriz com 107 caracteres morfológicos, e a busca por árvores foi realizada sob o critério de parcimônia. Das 46 espécies nominais incluídas na tribo antes desta revisão, 22 são consideradas válidas, 24 sinônimos são propostos e seis novas espécies são descritas; dessa forma, a tribo passa a estar composta por 28 espécies. Fornecemos uma chave para as espécies, bem como descrições detalhadas que incluem fotografias e ilustrações de adultos e terminálias. Além disso, a tribo é registrada pela primeira vez em dez países, doze espécies possuem novos registros geográficos em diferentes unidades administrativas (país, estado ou província), e onze espécies são registradas pela primeira vez em pelo menos um país. Nossa análise filogenética recuperou Telothyriini como um clado monofilético e, de acordo com nossos critérios, a tribo deve permanecer monogenérica, com apenas o gênero Telothyria. A reconstrução de estado ancestral sugere que o ancestral de Telothyriini não tinha pelos plumosos no disco do mesonoto, e que a transição para um mesonoto peludo ocorreu três vezes de forma independente, em uma das quais aconteceu uma transição posterior de pelos com plumosidade longa para pelo com plumosidade curta. Finalmente, consideramos os pelos plumosos um caráter convergente entre os Telothyriini e as abelhas.

Palavras-chave: Reconstrução do estado ancestral. Convergência. Pelos plumosos. Registro novo. Parasitoide. Parcimônia. Filogenia. Taquinídeo. Taxonomia. Telothyria. 


\section{GENERAL INTRODUCTION}

Tachinidae is one of the largest families of Diptera, only surpassed by Tipulidae, with 8592 described species worldwide (O'Hara et al. 2020; Pape et al. 2011). Tachinids flies are distributed in all zoogeographic regions, with the greatest diversity in the Neotropics (3088 spp. and 784 genera), although in the latter it is vastly under-estimated and its true size could be twice or several times larger than the already-large known fauna (O'Hara et al. 2020; O'Hara \& Henderson 2020). The tachinids have great ecological and economic importance because they present endoparasitoid habits, their larvae develop inside other arthropods, and in this way they contribute to the regulation of communities in natural ecosystems and have great potential as biological controllers of agricultural pests. Holometabolous insects' larvae constitute most of their hosts, mainly caterpillars, although they parasitize at least 15 orders of arthropods (Stireman et al. 2006).

Monophyly of Tachinidae has been historically recognized and is supported by traits of life history (endoparasitic habits), larval (larva I with strongly developed labrum) and adult morphology (bulky subscutellum) (Cerretti et al. 2014; Pape 1992; Wood 1987), as well as by molecular evidence (Stireman et al. 2019; Kutty et al. 2010). The classification and composition of Tachinidae has undergone important changes throughout history (O'Hara 2013), and currently four subfamilies are recognized (Dexiinae, Exoristinae, Phasiinae, and Tachininae) (O’Hara et al. 2020). This classification was supported by the most recent phylogenetic analysis of the family (Stireman et al. 2019), in which the following relationships were recovered Dexiinae + Phasiinae and Tachininae + Exoristinae, although this study also suggest that at least two additional subfamilies should be considered for the clades Macquartiini + Myophasiini (which formed a clade sister to all other Tachinidae) and Palpostomatini (part) + Imitomyiini (reconstructed as sister group to clade Dexiinae + Phasiinae)

Other phylogenetic studies have also helped to understand intertribal relationships, e.g. in Phasiinae (Blaschke et al. 2018; Dios \& Nihei in prep.), and to a lesser extent Exoristinae (Tachi \& Shima 2010; Stireman 2002); but despite these advances, rigorous phylogenetic studies are still necessary, especially at the level of genera, tribes and even subfamilies. For instance, in Dexiinae several of its main tribes (e.g. Voriini, Dexiini, Dufouriini) were not monophyletic in light of the results of Stireman et al. (2020), in addition some tribes were poorly represented (e.g. Telothyriini, Sophiini) or even not sampled (e.g. Iceliini, Trichodurini), which suggest the tribal classification needs a more complete analysis.

In relation to taxonomy, the Tachinidae are arguably the most difficult family of flies (O'Hara 2013). In addition to the high specific richness, the family currently has 1477 genera — most of them monotypic - which is almost double that registered in Cecidomyiidae (761), which occupies the second place (O'Hara \& Henderson 2020; Pape et al. 2011). Without a doubt where the problem is most evident 
is in the Neotropical region, in which in addition to being the most speciose region, it is also the most unknown and unexplored (O'Hara \& Henderson 2020; O'Hara 2013; Toma 2012). Another problem is that most of these genera and species were originally described without illustrations or with characters that currently do not present importance in their delimitations (Toma 2012). In addition, the taxonomic keys for tribes and genera in the Manual of Myiology (Townsend ${ }^{1}$ 1934-1942) - the largest for Neotropical fauna - are fraught with problems, making it difficult to recognize supraspecific taxa. So, the identification process requires the crossing of information from various sources that were made for specific areas, such as: the genera of Tachinidae from Central America (Wood \& Zumbado 2010), the tachinid fauna from Trinidad (e.g. Thompson 1963), and the Chilean Voriini (Cortés \& Gonzáles 1989). Finally, an additional but no less relevant limitation is the fact that most name-bearing types are found deposited in museums around the world, which are difficult to access for bureaucratic or financial reasons.

If we had to choose a taxon to represent all the problems previously described, Telothyriini (Dexiinae) would be an optimal candidate. This tribe has never been the focus of a systematic revision (neither taxonomic nor phylogenetic). Therefore, the objective of this project was to carry out the first phylogenetic study of Telothyriini based on a comparative morphological analysis, and to perform a comprehensive taxonomic revision. With our findings we were able to corroborate the monophyly of the tribe, we validated its generic classification and we resolved the taxonomic status of each of its nominal species that are now fully identifiable. We also hope that our results serve as the basis for future studies in the evolutionary, ecological, and applied fields.

\footnotetext{
${ }^{1}$ Charles Townsend was the most prolific of all tachinidologists, rarely included more than one species per genus and throughout his career described 1491 genera and 1555 species, with approximately $85 \%$ of the genera belonging to the Tachinidae (O’Hara 2013).
} 


\section{CONCLUDING REMARKS}

This is the first comprehensive taxonomic revision of the tribe Telothyriini composed only by genus Telothyria. Of the 46 nominal species previously included in the tribe, 22 are considered valid, 24 new synonymies are proposed, and six new species are described. Now, the tribe becomes composed of 28 species. The proposed synonymies allow us to know for the first time the male of T. brasiliensis and the females of T. bequaerti, T. placida, T. plumata and T. variegata. Telothyria schineri is considered a nomen dubium. An identification key for species is provided, as well as detailed descriptions that include photographs and illustrations of adults and terminalia. The known distribution of Telothyriini now covers 17 countries in Americas, in ten of them the tribe is recorded for the first time (Argentina, Bahamas, Colombia, Ecuador, Guiana, Honduras, Jamaica, Paraguay, Peru, and Venezuela). Furthermore, twelve species have new geographic records in different administrative units (country, state, or province), and eleven species are recorded for the first time in at least one country.

In same way, our study constitutes the first phylogenetic analysis of the tribe Telothyriini, being the only one at the tribal level into subfamily Dexiinae and the second for the family Tachinidae. The comparative analysis of the morphology of males and females allowed us to test 107 characters that under the criterion of parsimony yielded one single most parsimonious tree almost completely resolved. Regarding the outgroups, our sampling included taxa that had never been analyzed in a phylogenetic context, recovering the genera Prosenoides and Trichodura among the Dexiini. We can also suggest that Eriothrixina, or some of its members, is probably sister group of Telothyriini. Our phylogenetic reconstruction revealed the Telothyriini as a clearly natural well-supported lineage, and based on our analysis the tribe should remain monogeneric, with only Telothyria. The evolutionary reconstructions indicate that the ancestor of Telothyriini did not have feathery hairs on disc of mesonotum, and that transition to a hairy mesonotum occurred three times independently, in one of which a later transition from long to short feathery hairs was achieved. Finally, we consider that feathery hairs evolved convergently in Telothyriini, in bees and at least in the ant L. plumopilosus. Furthermore, we hypothesize that these hairs are mechanosensitive, an aspect that must be further tested. 


\section{GENERAL REFERENCES}

Blaschke J.S.; Stireman J.O.; O’Hara J.E.; Cerretti P. \& Moulton J.K. 2018. Molecular phylogenetics and piercer evolution in the bug-killing flies (Diptera: Tachinidae: Phasiinae). Systematics Entomology 43: 218-238.

Cerretti P.; O’Hara J.E.; Wood D.M.; Shima H.; Inclan D.J. \& Stireman J.O. 2014. Signal through the noise? Phylogeny of the Tachinidae (Diptera) as inferred from morphological evidence. Systematics Entomology 39: 335-353.

Cortés R. \& Gonzáles C.R. 1989. Géneros voriinos de tachinidos chilenos (Diptera: Tachinidae, Voriini). Memórias do Instituto Oswaldo Cruz 84: 115-123.

Dios R. \& Nihei S. in prep. Cladistic analysis of Phasiinae (Diptera: Tachinidae), based on morphological characters. Doctoral thesis. Zoology Deparment, Bioscience Institute, University of Sao Paulo. 215 pp.

Kutty S.N.; Pape T.; Wiegmann B.M. \& Meier R. 2010. Molecular phylogeny of the Calyptratae (Diptera: Cyclorrhapha) with an emphasis on the superfamily Oestroidea and the position of Mystacinobiidae and McAlpine's fly. Systematics Entomology 35: 614-635.

O'Hara J.E. \& Henderson S.J. 2020. World genera of the Tachinidae (Diptera) and their regional occurrence. Version 11.0. PDF document, 90 pp. Available from: http://www.nadsdiptera.org/Tach/WorldTachs/Genera/Gentach_ver11.pdf (accessed 30-082020).

O'Hara J.E. 2013. History of tachinid classification (Diptera, Tachinidae). ZooKeys 316: 1-34.

O'Hara J.E.; Henderson S.J. \& Wood D.M. 2020. Preliminary checklist of the Tachinidae (Diptera) of the world. Version 2.1. PDF document, 1039 pp. Available from: http://www.nadsdiptera.org/Tach/WorldTachs/Checklist/Tachchlist_ver2.1.pdf (accessed 3008-2020).

Pape T. 1992. Phylogeny of the Tachinidae family group (Diptera: Calyptratae). Tijdschrift voor Entomologie 135: 43-86.

Pape T.; Blagoderov V. \& Mostovski M.B. 2011. Order Diptera Linnaeus, 1758. In: Zhang, Z.-Q. (Ed.) Animal biodiversity: An outline of higher-level classification and survey of taxonomic richness. Zootaxa 3148: 222-229.

Stireman J.O. 2002. Phylogenetic relationships of tachinid flies in subfamily Exoristinae (Tachinidae: Diptera) based on 28S rDNA and elongation factor-1. Systematics Entomology 27: 409-435.

Stireman J.O.; Cerretti P.; O'Hara J.E.; Blaschke J.D. \& Moulton J.K. 2019. Molecular phylogeny and evolution of world Tachinidae (Diptera). Molecular phylogenetics and evolution 139: 106358. 
Stireman J.O.; O'Hara J.E. \& Wood D.M. 2006. Tachinidae: evolution, behavior, and ecology. Annual Review of Entomology 51: 525-555.

Tachi T. \& Shima H. 2010. Molecular phylogeny of the subfamily Exoristinae (Diptera, Tachinidae), with discussions on the evolutionary history of female oviposition strategy. Systematics Entomology 35: 148-163.

Thompson W.R. 1963. The Tachinidae of Trinidad. II. Echynomyiines, Dexiines and allies. Canadian Journal of Zoology 41: 335-576.

Toma R. 2012. Tachinidae: una discusión sobre el problema de la identificación de los taxones de la Región Neotropical. Entomotropica 27: 145-152.

Townsend C.H.T. 1934-1942. Manual of Myiology in twelve parts. Itaquaquecetuba: Charles Townsend \& Filhos. 3760 pp.

Wood D.M. \& Zumbado M.A. 2010. Tachinidae (Tachinid flies, parasitic flies). pp. 1343-1417. In: Brown B.; Borkent A.; Cumming J.; Wood D.; Woodley N. \& Zumbado M. (Eds). Manual of Central America Diptera, Vol. II. Ottawa: NRC Research Press.

Wood D.M. 1987. Tachinidae. pp. 1193-1269. In: McAlpine J.F.; Peterson B.V.; Shewell G.E.; Teskey H.J.; Vockeroth J.R.; Wood D.M. (Eds.). Manual of Nearctic Diptera. Vol. 2. Agriculture Canada Monograph 28. 